\title{
The Work Realities of Professional Studio Musicians in the German Popular Music Recording Industry: Careers, Practices and Economic Situations
}

\author{
Jan-Peter Herbst \\ University of Huddersfield \\ j.herbst@hud.ac.uk
}

\section{Tim Albrecht}

Independent scholar

tim.albrecht2@gmx.net

\begin{abstract}
Among the professional roles in the recording industry, studio musicians have received relatively little academic attention. The present study explores the work realities of professional studio musicians in Germany, one of the largest music industries in the world, and is based on interviews with six pop musicians; guitarists, bassists, keyboardists and drummers who are between 27 and 66 years old. The findings show how changes in the recording industry - most notably dwindling budgets, the rise of project studios and virtual collaboration - have affected working practices, skill requirements and business models. The findings indicate that in Germany it is hardly possible to make a living from studio work as a professional musician. This is true even for leading session players. Sinking fees and the lack of access to royalties pose a problem that is not tackled due to fierce competition and the risk of damaging one's reputation.
\end{abstract}

KEYWORDS: studio musicians, session musicians, recording industry, music business, Germany

\section{Introduction}

Despite the recent presence of studio musicians in films such as Hired Gun: Out Of The Shadows, Into The Spotlight (dir. Strine 2016), 20 Feet from Stardom (dir. Neville 2013) and Muscle Shoals - The Incredible True Story of a Small Town with a Big Sound (dir. Camalier 2013) as well as in books like The Wrecking Crew - The 
Untold Story of Rock \& Roll Heroes (Hartman 2013), little is publicly known about these musicians. All too often, the name of the individual who has played on a record, how the composition has been interpreted, or how the performances have been edited remains closed to the public. Although popular music is centred on celebrity figures and recognisable characters, much of it "is in fact made by unknown, unidentified musicians, hired collaborators who work out of the public eye in the recording studio or in the shadows of the concert stage" (Williams 2010: 59). The work of hired musicians seems to be a well-kept secret in the popular music business. But unlike Faulkner's (1971) description of session musicians as interchangeable labourers and MacLeod's (1993) characterisation as emotionally detached "hired guns" and "musical mercenaries", the unique musical skills and creative ideas of the many professional studio musicians have been essential for the popular music business in the last decades (Williams 2010: 59). The future of this profession yet seems uncertain considering the changes in the recording industry, especially the decreasing budgets (Burgess 2008), the closing of major studios (Leyshon 2009), the rise of home studio-based producers (Théberge 2012; Martin 2014) and decentralised network collaborations (Théberge 2004; Campelo and Howlett 2013; Koszolko 2017). When the digital audio workstation was established in the nineties, Skrepek (1994: 388) predicted the decline of the studio musician's profession. Campelo (2015) recently observed the decreasing number of session musicians in Portugal, while Williams (2010: 69) offered a negative outlook for the profession:

Nonmusical distractions and complications such as audience expectations, lack of recognition, inequitable pay scales, lack of job security, and the large amount of preparation and practice required to maintain the necessary skills each musician is expected to exhibit make freelancing a very difficult career to pursue.

In light of these changes, the present study explores the work realities of studio musicians working professionally in the popular music recording industry. Following Pierce's (1998: xviii) argument that "the only access (...) to understanding the session musician is through their own words, thoughts and feelings", this work is based on a qualitative interview design. The focus was directed on the German scene because the recording industry is governed by national regulations and professional societies. As one of the world's largest music industries, with a yearly turnover of 11 billion euros and 18,000 registered freelancing musicians plus 32,000 employed music professionals (Bundesverband Musikindustrie 2015: 9, 23), Germany is a considerable music scene. Within this context, the following questions guided the research project: How did the studio musicians find their way into this profession? What are the key criteria for a successful career in this business? What are the musicians' working practices like? How is their economic situation and how is it affected by the changes in the recording industry? The answers to these questions will provide an initial insight into the work realities of studio musicians in Germany that allow comparison of national practices in future work.

\section{Method}

The present study was inspired by recent work on record producers and music studio operators (Martin 2014; Auvinen 2016; Herbst and Holthaus 2017), continuing the young tradition of the Interpretative Phenomenological Analysis 
(IPA) in this field of research. IPA aims to "explore the participant's view of the world and to adopt, as far as is possible, an 'insider's perspective' of the phenomenon under study" (Smith 1996: 263-264). With this method, the respondents are given the opportunity to describe their experiences in their own words. It combines emphatic hermeneutics with questioning hermeneutics, a procedure that "is likely to lead to a richer analysis and to do greater justice to the totality of the person" (Smith and Osborn 2015: 26). This approach fitted the research project well due to the small body of literature on studio musicians.

IPA requires deliberate sampling, striving not for representativeness but for depth to gain detailed insights into the phenomenon in question (Smith, Flowers and Larkin 2009: 49). Gathering sample sizes of typically one to six participants seemed manageable, but proved difficult when it came to recruiting, let alone identifying, suitable musicians. In Germany, neither directories nor online platforms are available that list studio musicians. Studio musicians are rarely credited in liner notes and similarly, web searches rarely bring up any names. Worse, the German Wikipedia (2018) site on studio musicians only specifies US-American and British artists. For the most part, studio musicians are neither listed in the context of studios or labels due to their freelancing status. Consequently, a 'snowball sampling' (Cresswell 2013: 158) approach had to be applied whereby renowned players were addressed, asked for an interview and for recommendations of other adequate participants. Out of the approached ten musicians, six interviewees could be recruited: three guitarists, one bass player, one drummer and one keyboardist. Even if not widely known by the public, all were leading session musicians in Germany with a considerable degree of agency, alike the US-American session musicians in Williams' (2010: 59) study. Table 1 provides an overview of the participants, anonymised with labels for ethical reasons. The sample covered various regions in Germany. Even though all musicians except D1 had more than 25 years of professional experience, various levels of experience were still covered with an age difference of almost 40 years between the youngest and the oldest participant. Unfortunately, no professional female studio musician could be identified during the sampling process, which conforms with the underrepresentation of women in the recording industry in general (Negus 1996: 63f; Gibson 2005: 199f; Martin 2014; Auvinen 2016), and in the case of studio musicians (Fitzgerald 1996; Campelo 2015) ${ }^{1}$. As there are neither empirical studies nor official documents on gender in the German music industry, a discussion on the IASPM mailing list on "Famous UK session players" (14 and 15 October 2016) was analysed to estimate gender distribution in this profession in a geographically defined context close to Germany and with a music industry of a comparable size. From the 53 musicians listed in this discussion, a minority of five were women: one trombonist and four singers. This over-presence of female singers compared to instrumentalists complies with Campelo's (2015) professional experience of studio musicians in Portugal. In the light of this empirical evidence, the lack of female studio musicians in the present study must be considered unfortunate not allowing to capture the female experience, but accurate in terms of assumed quantitative distribution.

The data was gathered through semi-structured interviews with a schedule (Smith and Osborn 2015: 31-35) addressing topics such as the musicians' professional role and biography, practice habits, required skills, typical recording sessions and the economic situation. The six interviews were conducted between 13 and 16 May 2017; two via Skype, two per telephone and two face-to-face. The interviews took 40 minutes in average (27 to 66 minutes), which conforms to IPA standards (Smith and Osborn 2015: 35). 
TABLE 1. Sociodemographic data of the studio musicians

\begin{tabular}{|c|c|c|c|c|c|c|}
\hline Participant & 1 & 2 & 3 & 4 & 5 & 6 \\
\hline Instrument & Guitar & Guitar & Guitar & Keyboard & Drums & Bass \\
\hline Label & G1 & G2 & G3 & K1 & D1 & B1 \\
\hline $\begin{array}{l}\text { Musical } \\
\text { education }\end{array}$ & $\begin{array}{l}\text { Formal } \\
\text { education } \\
\text { in popular } \\
\text { music, jazz } \\
\text { and } \\
\text { classical } \\
\text { music in } \\
\text { music } \\
\text { schools } \\
\text { and } \\
\text { colleges }\end{array}$ & $\begin{array}{l}\text { Private music } \\
\text { tuition }\end{array}$ & Autodidact & $\begin{array}{l}\text { Degree in } \\
\text { classical } \\
\text { music } \\
\text { performance } \\
\text { at a university } \\
\text { of music }\end{array}$ & $\begin{array}{l}\text { Private } \\
\text { music } \\
\text { tuition }\end{array}$ & Autodidact \\
\hline Age & 48 & 55 & 61 & 52 & 27 & 66 \\
\hline State & $\begin{array}{l}\text { North } \\
\text { Rhine- } \\
\text { Westphalia }\end{array}$ & $\begin{array}{l}\text { Baden- } \\
\text { Wuerttemberg }\end{array}$ & $\begin{array}{l}\text { Schleswig- } \\
\text { Holstein }\end{array}$ & $\begin{array}{l}\text { Baden- } \\
\text { Wuerttemberg }\end{array}$ & Berlin & Bavaria \\
\hline
\end{tabular}

The transcription of the audio-recorded interviews matched IPA conventions, focussing on content rather than on prosodic aspects (Smith and Osborn 2015: 3738). Consequently, expressive gestures such as laughing, emphasis or pauses were not included. Each transcript was analysed separately, highlighting significant quotes and assigning them to topics. All interviews were categorised whilst retaining original quotes of the participants expressing their perceived realities in their own words (Smith and Osborn 2015: 49, 51). The quotes were translated from German into English. Since the focus was on the musicians' experiences, language errors and language-specific idioms were corrected for a better understanding.

\section{Results}

Analysing the work realities of studio musicians in Germany requires investigation of historical and contemporary conditions along with the musicians' individual biographies. Therefore, beginnings and developments of the respondents' musical careers will be explored first. After that, working practices in the studio and preparations of recording sessions will provide insights into the core of the profession. Ultimately, business models in the industry will be explored to understand the economic reality in this highly competitive field. Interpretation in the light of previous academic work will follow in the subsequent discussion to keep the description of the findings as objective as possible.

\section{Careers as a studio musician}

The participants found different ways into their profession as musicians. Only G2 took a deliberate decision.

It has always been my dream. Because when I started playing the guitar seriously, as a teenager, my favourite guitar players were well-sought studio 
guitarists. Larry Carlton and Lee Ritenour. In the '70s they were the studio guitarists who allegedly played five sessions a day, and as a teenager I dreamed of doing this too, although the studio scene in Germany would not allow it anyway (...). And then people started to notice that I could deliver, be able to fit into the music, and to cover both the technical and creative aspects of the job.

For other musicians like B1, the first studio experience was very influential on his future career:

When I was 19, my brother, 12 years older, took me to a studio, a famous one in Munich where all kinds of world stars had recorded. This was around 1967. There I sniffed studio air, could watch and listen. (...) And there I tasted blood. I felt this was exactly what I wanted to do. I also wanted to read my name on the album covers and I wanted the challenge to produce work that would still be heard in twenty years.

However, B1 did not start this career right away. The chance was offered to him after he got a record deal with CBS in 1975 to produce a demo with his original band. Deeply impressed with B1's bass playing, the sound engineer, who was formerly associated with The Beatles, passed B1's telephone number on to a producer. Soon after his first professional studio job, the newcomer became regionally known as one who could play modern styles well even though hardly capable of reading sheet music. B1 explained this is how it still works today.

G3, one of Germany's most successful and experienced studio musicians, initially did not believe in such a career as he thought he was not professional enough, mainly because he could not read sheet music well enough and did not own quality music gear. Nevertheless, he became member of a successful top forty band, whose more experienced players, convinced of his musical abilities, would take him to studio sessions. He sensed that he could make a living from studio work after four years, during which he developed a good track record of professional recordings.

D1 developed a similar career working extensively in many bands. He stressed the effort necessary to always be thoroughly prepared because several professionals assumed he could perform well without much practice. It did not take long for other musicians to notice D1's meticulous sense of detail in musical phrasing and sound, which helped him get his first studio jobs and made him realise his interest in this kind of work:

When I was in a studio for the first time, I noticed that the studio is something totally different from a live performance because you have completely different options, especially as a drummer (...). It was a completely different sound world. And since I had always been interested in new things, this was very intriguing because I was confronted with other challenges all the time.

Several renowned German film actors hired D1 for live jobs, which built up his reputation and extended his professional network, both earning him more studio jobs later in his career.

$\mathrm{K} 1$ also started his career as a live musician, but with his increasing interest in studio work he began producing on his own, an experience he regarded as valuable as he learned quite a bit about both instruments and their studio arrangement. His ability to think holistically about the final product was appealing to potential customers and gave him an advantage over mere instrument players. 
G1 saw his start as a session musician connected to the original bands he played in:

I have recorded many things with my own bands in studios. There they have seen how I did it and how fast I was. This was interesting to many studios back in those days because of the prospect to save time, and time is money. And suddenly many people in the studios I recorded at asked me. Many producers and sound engineers recommended me because of my fast working which was precious. With the analogue recordings back then, it was important how you played live because you did not have to edit so much.

Record labels soon began contacting G1 and interested musicians approached him at live shows. As such, his work extended to band coaching, arrangement and recording other bands.

All six interviewees highlighted technical and creative skills as beneficial for getting live gigs and studio sessions. Good performances were crucial for building an excellent reputation, which was important since all jobs depended on word-ofmouth recommendations. Social skills like patience and tolerance were common reasons for being booked again. The studio musician's role was likened to a psychologist, as B1 described. He and D1 both stressed how a positive attitude and humour improve the working atmosphere: "When you can keep the good mood at a session, then it is easier to work, and you objectively get better quality too. If you feel relaxed, you actually play differently". A positive mood contributed to a good relationship between the project partners, which increased the chances of being hired again.

Musical skills were described as decisive requirements for studio work, skills that had to be equally technical and creative to allow inventing ideas and performing these spontaneously to professional quality in various musical contexts. All musicians stressed the relevance of stylistic flexibility and related the importance of playing skills needed to elicit sounds from a variety of respective gear. B1 emphasised the need to be proficient in styles that are trendy and that may be requested during a certain time. Rejecting a job because of the genre would have a negative impact, potentially preventing the musician from being hired again by the employer. He explained there were no bad genres of music, only music that may be created badly. Therefore, it was important to cover a broad stylistic range from pop to rock, including traditional German popular music. For most of participants, the question was not whether they liked the music, but could they perform it. Only G1 accepted recording sessions in metal genres or other more exotic styles like flamenco requiring special practice and virtuoso skills.

Most of the participants are sought after internationally. Whilst K1 is more active in Germany, Austria and Switzerland, G1, G3 and B1 have worked in other European scenes and in the USA. However, not all productions made in Germany were for German artists or solely intended for the German market. B1 for instance mentioned recordings with Donna Summer and Boney M. in Munich. He further revealed some negative experiences of working internationally as it seldom came without its costs. The local professionals might be envious or even fear for their jobs, so that he often sensed an atmosphere of rejection. G3 described another issue working internationally. He refused several offers for major session work in the USA because he did not want to be separated from his children. This would be emotionally troublesome and had ruined several of his colleagues' lives. 


\section{Preparing a recording session}

Time is money, especially in the recording business. Preparing sessions and practicing however take time and keep one from doing other work. Only the youngest of the participants, drummer D1, practiced regularly. He would enjoy it and look towards phases when he could work on his skills. However, rather than performing technical exercises he would try to replicate album sounds in his own studio. G1 had practiced his playing technique a lot in the past but would not do so anymore as long as he could perform the ideas in his head. Few participants would do technical exercises regularly. B1 even admits never having practiced scales and technique in his over forty years as a professional musician. Working on his musicianship was what got him hired. G2 explained administrative tasks and acquisition of jobs would afford time often limiting his practising. If the studio musicians practiced, they would do so for particular projects. For example, G3 remembered the need to prepare a recent jazz recording: "If I hadn't practiced the stuff, I wouldn't have been able to play it. (...) It was very challenging technically. And because I practiced it a lot, I was able to play it fast". Practicing was mostly understood as coming up with new ideas and extending the stylistic repertoire, which was very useful for studio work but also more enjoyable than improving technique.

Sheet music was uncommon in most recording projects unlike in the past. B1 explained the musicians had often received sheet music that they briefly checked for difficult phrases. Nowadays, players usually improvise on pre-produced material or playbacks. Prior to the session, verbal descriptions or demo tracks served to introduce song concepts and compositional ideas. All participants agreed that preparation would mean being acquainted with the artist and the provided material. Learning the songs was uncommon as ideas that worked at home often did not do so in the session, or were not liked by the producer, as G1 described. Therefore, most ideas were improvised in the recording session. $\mathrm{K} 1$ further revealed that too much preparation was disadvantageous because of the risk of limiting the creative dialogue with the producer. Deciding on certain instruments and sounds in the recording sessions could lead to completely different performances and styles.

\section{Working in the studio}

All interviewees declared having a project studio. Although not all studios allowed for the recording of a live band, each participant stressed the professional quality of his studio. Very common were remote sessions where the hired professionals would record their instrument onto a basic track provided by the producer. An important benefit of such sessions was their lower costs. D1 explained that project studio work was necessary in times of shrinking budgets in the recording industry. For most professionals, the times of engineers taking over technical tasks were long gone. Even though some players in the business still refuse to engineer, all interviewees agreed this attitude was no longer one that could be held and remain competitive in the marketplace. According to D1, "It is vital to have a studio of your own. At least as a drummer. And I always find it strange how many drummers want to work in the studio but don't install a home studio. This way, they lose $50 \%$ of their potential jobs". Consequently, he believed drummers should have engineering skills at a level that would allow for the production of professional recordings. It was not necessary to be as proficient as a recording engineer was, but drummers should be able to set up the microphones at their kits, not only to have control over 
the sound, but also for economic reasons. To him, this was a simple calculation. A self-recording colleague of his would always have to book an engineer due to lacking engineering skills. Therefore, with a budget of $€ 400$ euros for the song and the engineer's share being $€ 200$, the financial loss of $50 \%$ of the budget made a huge economic difference. He further explained it was lucrative for his employers to hire musicians who have their own studios because the daily costs of recording in a professional studio would be much higher when one considers $€ 500$ for studio rent, $€ 200$ for an engineer plus the expenses for the studio musician. Yet he admitted that managing everything on his own would take greater effort since it was not possible to simultaneously play and monitor the signals when doing soundchecks. Furthermore, troubleshooting recording sessions could negatively affect creative work.

Apart from economic reasons, the more flexible work schedules were described as a major benefit of remote sessions. D1 outlined projects with actors whose dense schedules made it impossible to work together in the studio. If there were deadlines to be met, it was common practice to send a recording of the soundcheck to the producer, who either confirmed the sound or asked for corrections such as having certain instruments replaced, tuned or miked differently. Furthermore, the producer might request changes to the recordings, possibly wanting more fills or opening the hi-hat in different parts of a song. In such projects, the artist and the producer usually did not meet in person. All communication was done by phone, email or text message, thus saving costs for transport and studio rent.

Transportation was another important aspect of studio work as the musicians commonly brought large collections of equipment to sessions to be able to produce their sound. G1 preferred playing with his own gear because he knew how to achieve the intended result. If he played abroad, he would ask for identical equipment. For him and G3, guitar simulation and profiling amplifiers were unacceptable for their perceived inferior sound quality. To G2 however, a profiling amplifier was a major benefit because his personal sounds could be saved on a USB stick to be used everywhere. ${ }^{2}$ B1 was the only musician valuing a fast set up. Although he would also bring his gear, he would ask what was needed in advance to get ready within two minutes. G3 pursued a completely different approach. When he had recording jobs in the past, he commonly transported thirty guitars, fifteen amplifiers and diverse effects racks with his VW bus. This however had become too tedious, and the transport costs exceeded the average production budget. Therefore, he decided not to transport his equipment anymore and only to record in his own studio to keep effort and cost at bay.

Although all musicians used their own project studios for different kinds of jobs, most still appreciated recording at professional studios. G1 valued the greater quality whilst B1 highlighted a more professional workflow. Both agreed that compromises were inevitable when combining different roles such as player and engineer. Concentrating on playing rather than having multiple roles was more pleasurable, but also led to better results when professional engineers were responsible for the technical realisation. G1 had even come to a point where he refused to carry out multiple roles in hired jobs to not to risk his professional reputation by errors resulting from multitasking and lack of concentration. K1 had a slightly different view about the different working practices of professional studios. The biggest difference was not being able to record a live band in his home studio, but other than that, working at a project or professional studio was similar. Recording at a project studio could be more fragmentary but allowed more time to experiment. This might be good for the result, but occasionally it was also more time-consuming than necessary. 
Another reason why all musicians valued the professional studio was the immediate face-to-face relationship with the producer, which reduced misunderstandings that could increase the amount of work.

I prefer working with the employer because when you watch his reactions or talk to him, you find out faster what he needs, and then you come to an agreement faster. If you are working in isolation, then there is often a huge difference between what you think is needed and the reality. (G2)

K1 and G3 both complied with this line of thinking. G3 further stressed he did not like to puzzle over the producer's wishes just to do everything again after having received feedback on his ideas. He further explained that working in a team often led to unconventional results because other people convinced him to keep performances that did not go as planned but still were best for the song:

In many respects, it is a waste of time to compose and arrange on my own. Especially in pop music something important is missing you cannot find on your own. You need different people with their individual perspectives, who hear things differently and discover something in the material what I'd never noticed because at some point I don't see the forest through the trees anymore. Very, very often you try something out, just experiment with a sound, but you don't take the result seriously because you are not focused on the task. Then suddenly someone shouts 'Hey, that was awesome what you've just played. That's exactly what I was looking for!' These things happen all the time and lead to great results that wouldn't be possible without noticing these details. This is the beautiful thing about working in a team.

K1 agreed, highlighting the direct feedback being valuable not only for the sake of saving time because one would not need to record several alternative versions of each take, but also for the positive feeling of having satisfied his collaborators with his ideas.

Another benefit each participant saw in working at a professional studio was the opportunity to play with other musicians, which was their preferred way of recording. G3 nostalgically remembered a time when the musicians in original bands and session musicians learned and refined the songs in groups; the only difference was that session musicians had less time to practice. G2 favoured this more relaxed way of working too since the pressure was not on the musician, who in overdub productions, was in the spotlight. Furthermore, the final result could be heard immediately. The playing feel was another aspect emphasised by all musicians. As D1 described:

It just has a totally different kind of energy when playing with a band. And even though we have played to a click, it had more feeling and emotionality because you can see the bass player, hear how he plays a line, and you see the people making music.

This energy and feeling could not be achieved in a recording situation where every musician played in isolation. However, live recordings with a whole band were becoming rarer. G3 claimed the majority of jobs were for independent productions that seldom needed studio musicians because these were usually done by the original bands. In the case of modern pop productions, one of the studio musicians' main income sources, a digital audio file was commonly handed out with the request to play something similar to the template. 


\title{
Economic situation
}

All musicians agreed it was not possible anymore to make a living in Germany merely from studio work as used to be the case in the seventies and eighties. Each participant is thus forced to have several sources of income. K1 is also live keyboardist, producer and professor of music production. B1 makes productions for library companies in his professional home studio and plays in two live bands, whilst D1 records percussion and other sounds for films as well as making recordings for popular music productions in his studio. Making money at home worked well while waiting for live gigs, he explained. Moreover, he writes articles for musicians' magazines and plays in an original band. The conditions are similar for the three guitar players, all practicing several jobs as well. Being a permanent member of a renowned German pop band, teaching at several higher education institutions and having one's own bands applies to G2. G1 plays in original bands, holds part-time lectureships at universities, and operates his own music school. He also composes music for documentaries and audio plays, and arranges for classical orchestras. The freedom to choose and negotiate session work is only given to G3 by holding two professorships that ensure his living.

For their services as studio musicians all participants are paid similarly. Receiving royalties from the GEMA (German Society for Musical Performing and Mechanical Reproduction Rights) - the most lucrative kind of royalties in Germany - was rare as G3 noted that, "As a matter of fact, studio musicians had to be credited for their compositional work. But if you insisted on your share, this would have been the last job you did for that producer". While he believes it is his right to be paid fairly, he refrains from demanding it as it risks his future employment as a studio musician. If musicians insisted on their rights, producers and composers would fear that players who come up with good ideas might claim their share of the expected revenue. D1 as a drummer has no problem accepting this regulation. Contributing a drum groove is often not regarded as a composition, although the distinction may be blurry in certain cases, he admitted. Instead of being paid by the GEMA, the musicians could obtain money from the GVL (Collecting Society for Neighbouring Rights). These licences would bring just a few cents, as B1 explained, but could still be profitable if the record became successful. All participants agreed that their employers were keen not to let them participate in the royalties. Some could even be deceitful. Occasionally B1 had been requested to compose without being paid due to being at the session anyway:

\begin{abstract}
Actually, I am not merely a bass player, but I am an advisor as well. The people know I have played on so many hit records and of course they want my qualities on their productions too, which is fine. But it is something different when I am asked to compose complete form parts or so for free! Then understandably I'm not so happy to do so. But I have created original grooves for many, many bands and singers, most often together with the drummers and guitar players. This is no problem. I like to do that as long as it is within reason.
\end{abstract}

Whilst B1 was content to develop rhythmic grooves for the project, actual 'composing' was something different to him as it involved performing other roles, that of a composer or arranger, which are being paid differently and fall under separate neighbouring rights (GEMA instead of GVL). In order to ensure further jobs, B1 revealed that he would occasionally compose music free of charge.

As there are no unions for musicians in Germany that regulate fees for studio work, players must negotiate their pay for each project. In practice, flat session rates rather than hourly fees are standard paying terms for many of the studio musicians. 
D1 would usually negotiate a package price, which always was a risk. If he could manage to record the agreed number of songs quickly, then the hourly rate was satisfying, but sometimes it took longer than expected. K1 was also used to this method of payment, but his rate remained stalled despite his greater experience. Although his real income had significantly decreased, no higher rates could be claimed since the recording industry was so precarious. Compared to many of his colleagues whose number of jobs had declined over the years, he expressed still being satisfied with the demand for his services. G3 shed more insights into the paying practice and its historical development. As he explained, studio musicians used to get a fixed rate for a song and when offering their services on another instrument they could gain 50\% more pay for each one on top of their original commission. Business-minded guitarists thus tried adding overdubs with as many instruments as possible to increase their wage. This would have brought them DM 1,600 German marks for a song in the seventies and eighties. Even without these tricks these players could have earned DM 800 to DM 1,500 per song. When working for high-level employers, the costs for transport and hotels were paid separately. This luxury however has long gone and rates of approximately $€ 100$ per song are no rarity today. In the modern business climate additional instruments for tracks are rarely offered by these interviewees. Some of them would occasionally record simple lines on other instruments or do backing vocals but not at a level that merited additional pay. Even though it did not significantly increase their income, playing other instruments would at least help keep a good working relationship with potential future employers.

All participants expressed negotiating their rates to a various level of flexibility. To remain competitive, G3 does not work at a daily rate of $€ 1,500$ anymore. He explained that sometimes the budget of a single record was barely more than his former daily rate, but since he still wanted to work, he would agree to play for $€ 80$ an hour. For making such low rates at least a bit profitable, in exchange his employers had to come to his studio and book several hours. Fixed hourly rates were not an issue for most other participants as they usually adjusted the price to the project. D1, B1 and G1 expressed willingness to lower their rates for independent productions. "If I work for musicians who don't have a record deal, then I think about how low I can go because I don't want to hurt them. We find an agreement so that everybody is happy in the end", is G1's philosophy.

Apart from the reduced budgets, other circumstances have tightened the business. G2 explained that due to higher education programmes in popular music performance and production, more professional musicians were forced to share those few jobs that are available. The monopoly of limited studio resources and qualified musicians that catered to the recording business in the seventies and eighties did not exist anymore. G3 remembered a "time when the studio sector was flourishing and booming economically, and when you could afford a middle-class life as a studio musician". According to B1, the dwindling budgets of the record labels primarily affected the studio musicians because they were the ones who could most easily be economised. Especially the increasing technological capabilities of computer instruments had forced many of B1's colleagues to adapt in the nineties. In his experience, producers considered very carefully whether they hired a studio musician when programmed parts would do. The improving quality of instrument libraries could substitute for human musicians more and more. In this context, G2 highlighted that the affordability of powerful recording, sound-shaping and editing capabilities of modern digital audio technology had tightened the competition since semi-professional musicians, engineers and producers 
increasingly offered services for little money. Illegal music downloads and streaming services were other trends some of the musicians blamed for the precarious budgets today. Against the backdrop of such issues, B1 predicted the studio musician's profession becoming obsolete in ten or even five years "unless something unpredictable will happen so that people will refrain from computer music, but I don't think so".

Despite these negative economic circumstances, all interviewees emphasised that they loved their profession. The chance of being part of a hit record was one motivation they commonly shared. G3 explained that the many jobs requiring him to play music he did not like were balanced by his involvement in successful productions. Similarly, B1 felt greatly encouraged by having played on records still popular twenty or more years after their release. He was particularly proud of two productions. One was a recording in Italy that allegedly became a hit sold more than sixty million times, and the second was one of Germany's most successful singles within the last thirty-five years: "The people listening to it don't know who I am, but I know they are listening to me. That is great". Furthermore, he enthusiastically told stories of artists like Giorgio Moroder whom he worked with and inspired him.

Important motivators for several interviewees were the lack of routine and their daily challenges. G1 summarises,

It always is something new, it's never getting boring, it's always surprising. You can always discover something else. You get to know new people, new musicians, new music, new sounds, new studios. It just never becomes a routine. (...) I cannot describe my thirty years of a professional musician as a job because it is just fun, something that I do all the time. And I am incredibly happy to make a living from it.

D1 also emphasised the lack of routine as enriching. Live music involved playing the same songs repeatedly, and flexibility of performances was often limited because of the use of pre-programmed material. In a studio session however, new songs were played all the time, giving the possibility of coming up with something original. This resembled K1's joy of creating a memorable product from basic ideas. B1 and G2 were even more humble and each stressed the privilege to make a living from music.

\section{Discussion}

Existing academic literature, manuals and common beliefs suggest that studio "musicians have to have the highest possible levels of instrumental (or vocal) skill (...). There is absolutely no room for any kind of imperfection in professional recording" (Hannan 2003: 61). Costly studio time is one important reason according to Field (2004: 232), "There is usually not a lot of time for rehearsals, and because of the high studio cost of studio personnel and time, mistakes are not tolerated". Considering such demands, Williams (2010: 64) listed four main attributes of successful session and studio musicians: a broad stylistic range, the ability to translate ideas across genres, reliability and consistent quality, and delivering the unexpected. Ideally, the studio musician added something to the composition or led the recording into new directions (Campelo 2015), thus creating "moments of greatness" as described by producer Phil Ramone (Granata 2007: 38). Songwriter Lynch in Fitzgerald's (1996: 73) study similarly revealed requiring collaborators "who are capable, if not more than capable, to bring something out 
of the song that I couldn't see". Complying with this, Williams (2010: 63) claimed highly refined and diverse skills as a "prerequisite for admission into the upper echelon of studio work" but it was the "musician's unique ability to assess and adapt his or her 'way' that makes one a desirable hire". Session guitarist Rex Goh in Fitzgerald's (1996: 72) Australia-based study confirmed these claims:

They call you to a session, you know, because of your ability to play the guitar, but also for your ideas. The ones with the better ideas will always get the work. About $80 \%$ of the time they want my input...You know they don't have the ideas that guitar players have.

The participants of this study all verified the shift from playing composed parts in the sixties and seventies to improvisation in modern times. Instrumental parts were rarely notated. The musicians play by ear and develop ideas from simple lead sheets. They further must be open towards different styles and genres to play as many sessions as possible (Field 2004: 232), but they must also be up-to-date regarding modern styles and sounds. All interviewees stressed the challenge of following musical trends for many decades whilst keeping a personal style for being hired. Instrumental virtuosity was not regarded as crucial for the profession, since most often the contribution had to fit to the song, which could involve having to play like a beginner on a cheap instrument to achieve the requested sound and feel. All musicians described themselves as being very sound-conscious and hence go to considerable length transporting and setting up various gear for a session. This also complies with session guitarist Goh in Fitzgerald's (1996: 70) study:

I'Il have my own set of sounds that I use, and they're just guidelines. I have a power chord sound, I have a clean sound, I have a bluesy sound - about ten sounds that I pre-program, either on my rack or up in my head.

Having many sounds available is a basic requirement of a studio musician (Lyng 2007: 172). Since transporting all the necessary equipment to an external recording studio is a big effort, most of the interviewees installed a specialised recording space of their own.

Recent research (Théberge 2004; Koszolko 2017) has highlighted changes in the production sector and the emergence of the network studio. The present findings stress the studio musicians' need for a personal project studio of professional quality and the importance of engineering skills. Remote sessions have become common, and especially the younger musicians work more in project studios than they do in major studios. Consequently, having engineering skills for their own instrument has become a major benefit for musicians because recordings are cheaper for the employer. Also, not having to pay for an engineer in remote sessions increases the player's income. Furthermore, knowing about the possibilities of modern production tools helps musicians determine what could be contributed to a session and how to do it. Musicians with recording skills thus have an advantage over musicians who can only play. Also, according to the interviewees, young producers and engineers often did not have the technical foundation of experienced professionals socialised in the days of analogue recordings. Such engineering experience could help making the sessions more efficient, thus benefitting the hourly rate of every project partner when being paid a flat fee. Moreover, this extended skillset of musicians with profound engineering experience may affect the power dynamics between the musicians and the producers, potentially 
strengthening the musicians' basis for negotiation with employers regarding payment and authorship.

The findings demonstrate the dwindling budgets clearly affecting the recording industry. This was different twenty years ago when Pierce (1998: xv) displayed a promising picture about the studio musician's profession in the USA:

Most of them work six days a week, playing two sessions a day. (...) Session musicians are always booked, and must be hired several months in advance to play on a session. However, they no longer have to go out on the road (...).

Contrary to the generous annual salary of $\$ 100,000$ or more Field described (2004: 232) for the US-American recording industry, the interviewees agreed it was not possible anymore to make a living exclusively from studio work, at least not in Germany. Commercial live music and teaching are vital sources of extra income for all of them, which complies with official statistics showing that over half of the freelancing musicians in Germany have more than one job (Bundesverband Musikindustrie 2015: 13). Like in Portugal (Campelo 2015), the number of studio jobs has decreased since the 1990s due to significant changes in the industry and technological 'competitors' such as high-quality drum computers and virtual instruments, which eventually led to falling rates. The musicians not only showed a willingness to negotiate their fees, they would also accept short notice requests although preferring to schedule their session work several weeks in advance. This situation concurs with Williams' (2010: 69) account of the US-American studio scene, according to which studio musicians suffer from financial insecurity, difficulty of planning, extensive preparation as well as from the high demands on their musical skills. What is more, the financial problems Fitzgerald (1996) described parallel the findings of this study. In Australia, royalties are not shared with session musicians unless those are credited as composers. Studio guitarist Goh expressed frustration with this system.

In America like the big session players in certain situations have got royalties ... I'd like to see that [in Australia], because a lot of the time we get paid a flat session rate, and you know that song, it's a big hit all over the world ... and compared to what the writers get and what the producers get we get virtually nothing. (Fitzerald 1996: 74)

Similarly, arranger Millward felt frustrated that his deserved share of royalties was resisted by the writers (Fitzgerald 1996: 73). Both views resemble those of the musicians of this study. None of them profits from lucrative GEMA royalties despite their important contribution to the product, and no one takes legal actions to stay employable. ${ }^{3}$ The market with its many well-educated musicians and programmers of high-quality computer instruments (Klein 2016) has become too competitive to put off potential employers and damage one's reputation.

Regarding the question of authorship, it remains debatable what services employers can expect from hired musicians. Although expert playing skills and stylistic knowledge are likely to be included in the musician's services, the boundaries between mere professional competences and original contribution worthy of compositional recognition are blurry. This matter is further intensified by national legal regulations. Whilst the copyright law in the US-American tradition, applicable also in the UK and the Commonwealth, regulates the economic interests of entrepreneurs (the "right to copy"), the German 'Urheberrecht' (the "author's rights"), originally developed to protect art, literature and music, secures the 
intellectual, artistic and economic rights of its creator (Urheberrecht 2018). Under the 'Urheberrecht', the author, commonly original artists, composers and arrangers, can grant their right of use to entrepreneurs (that is, record labels), who then become the "copyright holder". However, original artists can never lose their author's rights, which are inextricably tied to exploitation rights (Urheberrecht 2018). ${ }^{4}$ As the threshold for the eligibility of works for protection is not clearly defined for musical practice because even minimal levels of creativity, called "small coin", are worthy of protection, legal cases must be decided with the help of professional experts on a case by case basis (Rösing 2012: 259-262). Since only minimal levels of creativity are required, at least some of the studio musicians' contributions theoretically should be a protectable merit legally. ${ }^{5}$ Yet due to the lack of universal rules and the employers' intentions to restrain compositional authorship, studio musicians often fall short of having their artistic contribution legitimately credited and compensated. As a result, they miss out on the lucrative neighbouring rights of the GEMA. Instead they only have access to payouts of the GVL which has a much smaller budget (Bundesverband Musikindustrie 2015: 65). In 2014, both societies had a common gross budget of $€ 1,057$ million, GEMA $€ 894$ million and GVL $€ 163$ million. GVL's net sum of $€ 113$ million was shared evenly between artists and record labels, thus the artists' sum of $€ 56.5$ million was less than ten percent of GEMA's net value (€756 million), resulting in huge income differences between the professions. Composers and writers of music had a mean income of $€ 51,100$ in 2014, whilst musicians only earned $€ 12,500$ (Bundesverband Musikindustrie 2015: 22-24). This huge discrepancy is due to the sources of income; composers earned $58 \%$ from royalties and further $22 \%$ from fees, but musicians only benefit rudimentary from royalties (GEMA 13\%, GVL 9\%). Fees for live gigs (36\%) are their main source of income (Bundesverband Musikindustrie 2015: 22-24). In comparison, music producers lived mainly from fees $(65 \%)$ and received a significantly low amount of royalties (9\%) (Bundesverband Musikindustrie 2015: 42). However, with an overall income of $€ 73,300$, music producers were among the top earners in the music industry (Bundesverband Musikindustrie 2015: 46). In the context of the production sector musicians have the chance of earning considerable fees and royalties when working with successful employers. The recording industry (gross $€ 3,104$ million) and the live industry (gross $€ 3,168$ million) are the two of the seven sectors in the German music industry (total of $€ 11$ billion) making the largest amount of Euros in terms of sales (Bundesverband Musikindustrie 2015: 38, 46). ${ }^{6}$ Since many more people work in the live sector - concert promoters, bookers, service jobs, technical assistants and gastronomy - than in the recording business, excellent musicians have the chance of making a considerable income through studio work. Even though record sales have halved since the 1990s (Bundesverband Musikindustrie 2015: 40), the average income in the recording sector $(€ 44,300)$ has been significantly higher than in the live sector $(€ 31,900)$ (Bundesverband Musikindustrie 2015: 14). ${ }^{7}$ But as other research on music producers and studio operators has shown (Herbst and Holthaus 2017), it has become very challenging in Germany to live as a music creative solely from work in the recording studio unless one belongs to the top class of musicians who have an international reputation.

This work reality is very similar amongst music producers in the USA (Burgess 2008). With the US record sales having declined more than a third since 2004 and an average recording budget of less than $\$ 30,000$ inclusive producer and engineer fees, many producers have been struggling. 
To make a substantial living as a producer-for-hire is much more difficult than it was five years ago. The producer of today has to be more creative about finding work and more knowledgeable about potential sources of income. (...) In order to make a living the producer of today needs to be proactive in seeking out work, very often performing A\&R duties in scouting new artists or reviving older ones. (...) Since the advent of Pro-Tools/computer-based recording and the increasing cost effectiveness of the home or project studio most producers now have some kind of facility of their own. There has been a strong trend towards the engineer-producer or at least the producer who can engineer somewhat. (Burgess 2008)

Burgess describes trends for producers paralleling the studio musician. Not only taking over technical roles to reduce the costs, the producers also attempt to be credited artistically to earn their share on royalties. While they are often not credited as a composer, producers often try to be credited as a "performing producer" who either contributes an instrumental or vocal performance to the production or conducts an ensemble during a recording (Burgess 2008). This is particularly difficult in the USA (DCMA) but easier in the UK (Music Producers Guild), Germany (GVL) and Norway (GRAMO). Studio musicians in Germany can have their share within the composers and performers societies, but their regular fees, much less than the producers', make their economic situation far more precarious.

Despite these challenges and economic insecurities, all interviewees enjoy their profession in a similar manner as concluded by Williams (2010: 69),

The degree of emotional and intellectual engagement demonstrated by the musicians of this study should dispel any myth of the distanced, jaded, "hired gun." (...) in reality, these musicians are often fully committed, gleefully diving into the center of the projects they work on.

The German musicians are grateful for being able to make a living from music and they enjoy the challenges of working with different artists and inspiring people, playing many genres of music and being part of productions that last.

\section{Conclusion}

Twenty years ago, Skrepek (1994: 388; translation) predicted the decline of the profession of studio musicians, "The job (...) has become obsolete, everything is computerised. (...) We are heading towards a future where machines are entertaining us". Although this study does not support such a gloomy outlook, the present findings still demonstrate how the shrinking budgets in the recording industry influence studio musicians negatively. As their income dwindles, additional occupations become necessary, and those few jobs remaining are the sources of fierce competition. Technological developments that greatly affected the recording business as a whole have had an impact on the studio musician's profession too. On the one hand, the increasing availability of music production tools has forced studio musicians to acquire engineering skills, which on the other hand raised new prospects for dedicated recording professionals to specialise and set themselves apart from their competitors. Yet, the ever-progressing quality of instrument libraries and programmable instruments poses a threat endangering the studio musician's profession. Today, however, the studio musician still has an important role to play in the popular music recording industry. 
Considering the modest amount of research on studio musicians in popular music studies and the art of record production, more studies are required. Potential gender differences in studio musicians and recording spaces may be another field of study, an issue left out in this study since no female musician could be interviewed. Given the importance of power hierarchies for the regulations around payment and authorship, it would be interesting to explore how the common chauvinist prejudgement of women allegedly lacking musical skills, described by Campelo (2015) in the case of female session singers, affects their basis for negotiations. The small sample size further did not allow reliable analyses on differences between instruments, regional characteristics and levels of experience. What is more, national differences could be worked out in greater detail based on studies focusing on America (Williams 2010), Australia (Fitzgerald 1996) and Portugal (Campelo 2015). Furthermore, many national music industries are still blind spots. Studio musicians in these various scenes might work under different copyright and 'Urheberrecht' regulations, and they may be represented by unique musician's unions, significantly affecting their economic situation. Future research might dedicate itself to such questions to shed light on the popular music recording industries, which could also increase the visibility of studio musicians in music research.

\section{Endnotes}

1 Williams (2010) in his study on the creative identity of hired musicians discloses neither the size nor the gender distribution of his sample. However, he describes a female singer, thus supporting the assumption of women predominantly working in the role of vocalists in the recording studio.

2 For an empirical investigation into guitar profiling technology see Herbst, CzedikEysenberg and Reuter 2018. For interviews of German metal music producers on the use of profiling technology in the studio see Herbst 2019.

3 In Germany there is no musicians' union effectively protecting their neighbouring rights. While an official artists' social insurance ('Künstlersozialkasse') grants health, care and pension insurances to freelance musicians, it does not offer legal advice. The GVL is the only institution representing the interests of recording artists, taking care of their neighbouring rights to forestall exploitation (https://www.gvl.de/en/gvl/about). However, as the interviews indicate, this institutional protection does not seem to be sufficient to prevent exploitation in common practice.

4 With the reform in 2007, a new 'buy-out' option has been integrated to the 'Urheberrecht'. It still secures authoring rights, even though authors may now relinquish their exploitation rights (Rehbinder 2008: 224f).

5 Another complication of this regulation is that theoretically every credited author, from the composers, arrangers, producers to the musicians, would have certain exploitation rights, unless they sign the 'buy-out' clause.

6 The $€ 11$ billion in sales are distributed as follows (in million): $€ 3,168$ live music, $€ 3,104$ recorded music, $€ 1,882$ musical instruments, $€ 1,057$ collecting societies, $€ 715$ writers and authors, €586 music education, €555 music publishers (Bundesverband Musikindustrie 2015: 14).

7 Compared to music publishers $(€ 66,600)$ and musical instruments retailers $(€ 51,600)$, live and studio sector work is paid significantly less than these two, yet it is still better than the average wage within the German music industry $(€ 30,700)$. Live and studio work is more profitable than teaching $(€ 13,500)$, which is at the bottom end of the music professions (Bundesverband Musikindustrie 2015: 14). 


\section{Acknowledgements}

Another article based on the same interview data is published in the Finnish Yearbook of Ethnomusicology (Herbst and Albrecht 2018). Its focus lays on the required skill set of studio musicians and how it compares to musical scenes around the globe at different times in popular music history

\section{References}

\section{Bibliography}

Auvinen, T., 2016. A New Breed of Home Studio Producer. Etnomusikologian vuosikirja 28: 1 - 33 .

Bundesverband Musikindustrie, 2015. Musikwirtschaft in Deutschland. Studie zur volkswirtschaftlichen Bedeutung von Musikunternehmen unter

Berü cksichtigung aller Teilsektoren und Ausstrahlungseffekte. Berlin: Bundesverband Musikindustrie.

Burgess, R. J., 2008. Producer Compensation: Challenges and Options in the New Music Business. Journal on the Art of Record Production 3, 1 - 9.

Campelo, I., 2015. 'That Extra Thing'- The Role Of Session Musicians In The Recording Industry. Journal on the Art of Record Production 10, July 2015.

Campelo, I. and Howlett, M., 2013. The 'virtual' Producer in the Recording Studio: Media Networks in Long Distance Peripheral Performances. Journal on the Art of Record Production 8, December 2013.

Cresswell, J. W., 2013. Qualitative Inquiry and Research Design. Choosing Among Five Approaches. Los Angeles: Sage.

Faulkner, R. R., 1971. Hollywood Studio Musicians. Their Work and Careers in the Recording Industry. Chicago: Aldine-Atherton.

Field, S., 2004. Career Opportunities in the Music Industry. 6. ed. New York: Checkmark Books.

Fitzgerald, J., 1996. Down into the fire. A case study of a popular music recording session. Perfect beat. The Pacific journal of research into contemporary music and popular culture 5 (3): $63-77$.

Gibson, C., 2005. Recording Studios: Relational Spaces of Creativity in the City. Built Environment 31 (3): 258 - 273.

Granata, C., 2007. Making Records - The Scenes Behind the Music - Phil Ramone. New York: Hyperion.

Hannan, M., 2003. Australian Guide to Careers in Music. Music Council of Australia. Sydney: UNSW Press.

Hartman, K., 2013. The Wrecking Crew - The Untold Story of Rock \& Roll Heroes. New York: St. Martin's Griffin.

Herbst, J.-P., 2019 (forthcoming). Old sounds with new technologies? Examining the creative potential of guitar 'profiling' technology and the future of metal music from producers' perspectives. Metal Music Studies 5 (1).

Herbst, J.- P., and Albrecht, T., 2018. The skillset of professional studio musicians in the German popular music recording industry. Etnomusikologian vuosikirja 30: 121 - 153. DOI: doi.org/10.23985/evk.69085.

Herbst, J.-P., Czedik-Eysenberg, I. and Reuter, C., 2018. Guitar profiling technology in metal music production: public reception, capability, consequences and perspectives. Metal Music Studies 4 (3), 481 - 506.

Herbst, J.-P. and Holthaus, J., 2017. Music studio operators from Germany's 'Ruhrpott'. Role, services and resources. Etnomusikologian vuosikirja 29: 1-30. 
Klein, S., 2016. Feigning Humanity: Virtual Instruments, Simulation and Performativity. IASPM@Journa/6 (2): 23 - 48.

Koszolko, M. K., 2017. The Giver: A Case Study of the Impact of Remote Music Collaboration Software on Music Production Process. IASPM@Journa/ 7 (2): 32 $-40$.

Leyshon, A., 2009. The Software Slump?: digital music, the democratisation of technology, and the decline of the recording studio sector within the musical economy. Environment and Planning A 49: 1209 - 1331.

Lyng, R., 2007. Die Praxis im Musikbusiness. Musterverträge, Promotion, Booking, Management, Label und Vertrag, GEMA/GVL. 10. ed. Bergkirchen: PPVMEDIEN.

MacLeod, B. A., 1993. Club Date Musicians: Playing the New York Party Circuit. Urbana: University of Illinois Press.

Martin, A., 2014. The Role and Working Practice of Music Producers: An Interpretative Phenomenological Analysis. PhD. University of Hull, Hull.

Negus, K., 1996. Popular Music in Theory. An Introduction. Cambridge: Polity Press.

Pierce, J. E., 1998. Playin' around. The lives and careers of famous session musicians. Lanham: Scarecrow Press.

Rehbinder, M., 2008. Urheberrecht. München: C. H. Beck.

Rösing, H. 2012. Forensische Popmusik-Analyse; In D. Helms and T. Phleps Eds. Black Box Pop. Analysen populärer Musik. Bielefeld: transcript: 257 - 277.

Smith, J., 1996. Beyond the Divide Between Cognition and Discourse: Using Interpretative Phenomenological Analysis in Health Psychology. Psychology of Health 11 (2): 261 - 271.

Smith, J., Flowers, P. and Larkin, M., 2009. Interpretative Phenomenological Analysis. Thousand Oaks: Sage.

Smith, J. and Osborn, M., 2015. "Interpretative Phenomenological Analysis". In J. Smith Ed. Qualitative Psychology. 3. ed. Thousand Oaks: Sage: 25 - 52.

Skrepek, P. P., 1994. Studiomusiker einst und jetzt. In P. W. Forst Ed. Zur Situation der Musiker in Usterreich. Referate der Musik-Symposien im Schloss Schlosshof (1989-1993). Vienna: Institut für Wiener Klangstil: 381 - 389.

Théberge, P. -

2004. The Network Studio: Historical and Technological Paths to a New Ideal in Music Making. Social Studies of Science 34 (5): 759 - 781.

2012. The End of the World as We Know It: The Changing Role of the Studio in the Age of the Internet. In S. Frith and S. Zagorski-Thomas Eds. The art of record production. An introductory reader for a new academic field. Farnham: Ashgate: 77 - 90.

Williams, A. 2010. Navigating Proximities: The Creative Identity of the Hired Musician. Journal of the Music and Entertainment Industry Educators Association 10 (1): 59 - 76.

\section{Web Sources}

Urheberrecht, 2018. Copyright: Worin unterscheidet es sich vom Urheberrecht? https://www.urheberrecht.de/copyright. Accessed 21 April 2018.

Wikipedia, 2018. Studiomusiker. https://de.wikipedia.org/wiki/Studiomusiker. Accessed: 16 Apr 2018. 


\section{Filmography}

Camalier, G., 2013. Muscle Shoals - The Incredible True Story of a Small Town with a Big Sound. Ear Goggles.

Neville, M., 2013. 20 Feet from Stardom. Gil Friesen Productions.

Strine, F., 2016. Hired Gun: Out Of The Shadows, Into The Spotlight. Drama Kills.

\section{Interviews}

G1. 2017. Interviewed by Author, Detmold, 13 May. Conducted via phone. G2. 2017. Interviewed by Author, Bielefeld, 15 May. Face-to-face interview. G3. 2017. Interviewed by Author, Detmold 15 May. Conducted via Skype. K1. 2017. Interviewed by Author, Bielefeld, 15 May. Face-to-face interview. D1. 2017. Interviewed by Author, Detmold, 16 May. Conducted via Skype. B1. 2017. Interviewed by Author, Detmold, 16 May. Conducted via phone. 